\title{
Kajian Stabilitas Wahana Angkut ALPO sebagai Fungsi Kapasitas Tangki Ballast
}

\author{
Arifin $^{1 *}$, Wibowo Harso Nugroho. ${ }^{1}$, Sahlan $^{1}$ \\ ${ }^{1}$ Pusat Teknologi Rekayasa Industri Maritim (PTRIM) - BPPT \\ Jl. Hidrodinamika, Kampus ITS Sukolilo - Surabaya \\ *Email: arifinsah03@gmail.com
}

DOI: 10.25042/jpe.112018.08

\begin{abstract}
Abstrak
Data SKK migas menjelaskan bahwa terdapat sekitar 449 anjungan lepas pantai yang umurnya lebih dari 30 tahun, dan bahkan sudah tidak berproduksi lagi. Dalam kaitannya dengan keselamatan pelayaran dan berdasarkan regulasi IMO, anjungan lepas pantai tersebut perlu untuk segera dibongkar atau dipindahkan. Dalam rangka untuk mendukung kegiatan pembongkaran dan pemindahan anjungan lepas pantai pasca operasi (ALPO), diperlukan suatu perencanaan dan analisis wahana agar dapat dipergunakan untuk melakukan tujuan tersebut secara efektif dan aman. Suatu kajian dengan metode pendekatan numerik dilakukan terhadap perencanaan wahana angkut ALPO yang berupa analisis stabilitas intact kapal pada berbagai kondisi operasional kapal terutama saat departure, loading dan arrival dengan mengacu pada kriteria stabilitas yang diberikan oleh DNV atau IMO. Khusus untuk kondisi loading, kajian dilakukan dengan memvariasikan pengisian tangki ballast dalam bentuk prosentase kapasitas tangki ballast. Dari kajian ini dapat diketahui bahwa wahana angkut ALPO yang direncanakan dapat memenuhi kriteria stabilitas intact, terutama untuk kondisi saat departure dan arrival. Sedangkan untuk kondisi saat loading, kriteria stabilitas dapat dipenuhi pada kondisi pengisian $40 \%$ kapasitas tangki ballast kapal.
\end{abstract}

\begin{abstract}
Stability Study of ALPO Transport Vehicle as a Function of Ballast Tank Capacity. SKK Migas data explains that there are around 449 offshore platforms that are more than 30 years old, and even no longer produce. In relation to shipping safety and based on IMO regulations, the offshore platform needs to be immediately dismantled or moved. In order to support the demolition and removal of postoperative offshore platforms (ALPO), a vehicle planning and analysis is needed so that it can be used to carry out these objectives effectively and safely. A study with a numerical approach is carried out on the planning of ALPO transport vehicles in the form of intact stability analysis of ships in various ship operational conditions, especially during departure, loading and arrival with reference to the stability criteria given by DNV or IMO. Especially for loading conditions, the study is carried out by varying the ballast tank filling in the form of a percentage of ballast tank capacity. From this study it can be seen that the planned ALPO transport vehicle can meet the intact stability criteria, especially for conditions at departure and arrival. Whereas for loading conditions, the stability criteria can be met under conditions of filling $40 \%$ of the capacity of the ship ballast tank.
\end{abstract}

Kata Kunci: ALPO, kapasitas ballast, keselamatan, numerik, stabilitas

\section{Pendahuluan}

Indonesia sebagai negara penghasil minyak dan gas, menurut data SKK - Migas 2014 pada umumnya menggunakan Jacket platform untuk eksplorasi dan eksploitasi minyak dan gas bumi. Struktur ini umumnya terpasang di laut lepas (offshore). Anjungan lepas pantai ini terdistribusi sekitar $65 \%$ di perairan P. Jawa, 25\% di daerah Kalimantan Timur dan sisanya berada di Selat Malaka, Natuna dan Jatim. Bentuk strukturnya berkisar $40 \%$ berkaki empat, $34 \%$ berkaki tiga dan sisanya adalah monopod. Dari jumlah sekitar
449 anjungan lepas pantai ada sekitar 38\% umurnya sudah lebih dari 30 tahun, padahal umur dari dari konstruksi anjungan lepas pantai umumnya berkisar antara $20 \mathrm{~s} / \mathrm{d} 40$ tahun. Dari sumber data yang sama diketahui juga bahwa sebagian besar anjungan lepas pantai tersebut juga sudah semakin menurun produksinya sehingga sudah tidak menguntungkan lagi (ditinjau dari segi ekonomi) dan sebagian anjungan sudah habis masa operasionalnya.

Dalam kaitannya dengan keselamatan pelayaran, suatu anjungan yang sudah tidak 
beroperasi dan diinstall di kedalaman laut kurang dari $100 \mathrm{~m}$, dan berat anjungan (tipe jacket) kurang dari 4000 ton, maka anjungan tersebut harus dibongkar dan dipindahkan seluruhnya [1].

Berdasarkan data sebaran lokasi ekplorasi migas di Indonesia Tahun yang dikeluarkan oleh
PwC Indonesia (lihat Gambar 1), diketahui bahwa sebagian besar lokasi anjungan tipe terpancang terletak dekat dengan alur lalu lintas pelayaran, Gambar 2. Hal ini sudah barang tentu akan mempunyai potensi resiko yang cukup besar terhadap terjadinya kecelakaan kapal.

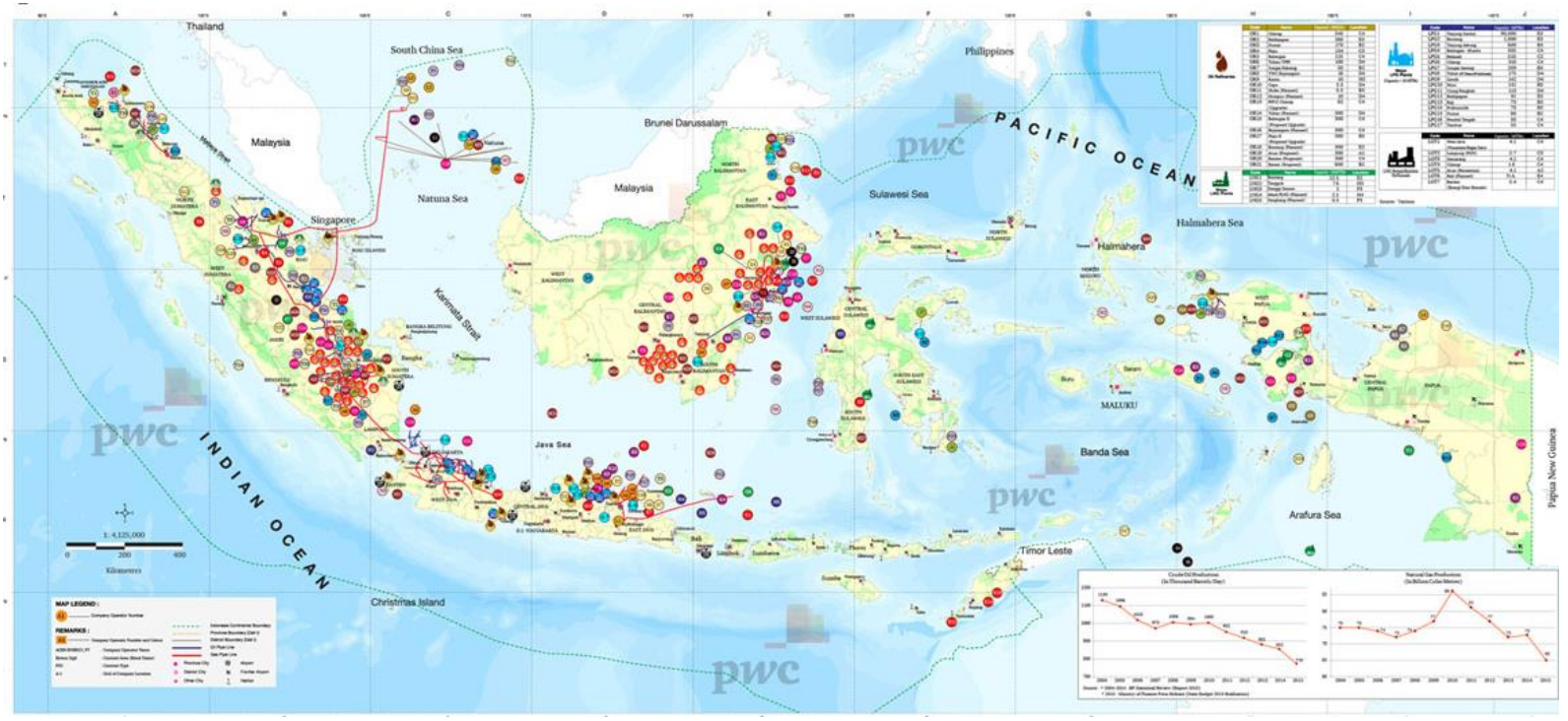

Gambar 1. Peta infrastruktur migas di indonesia

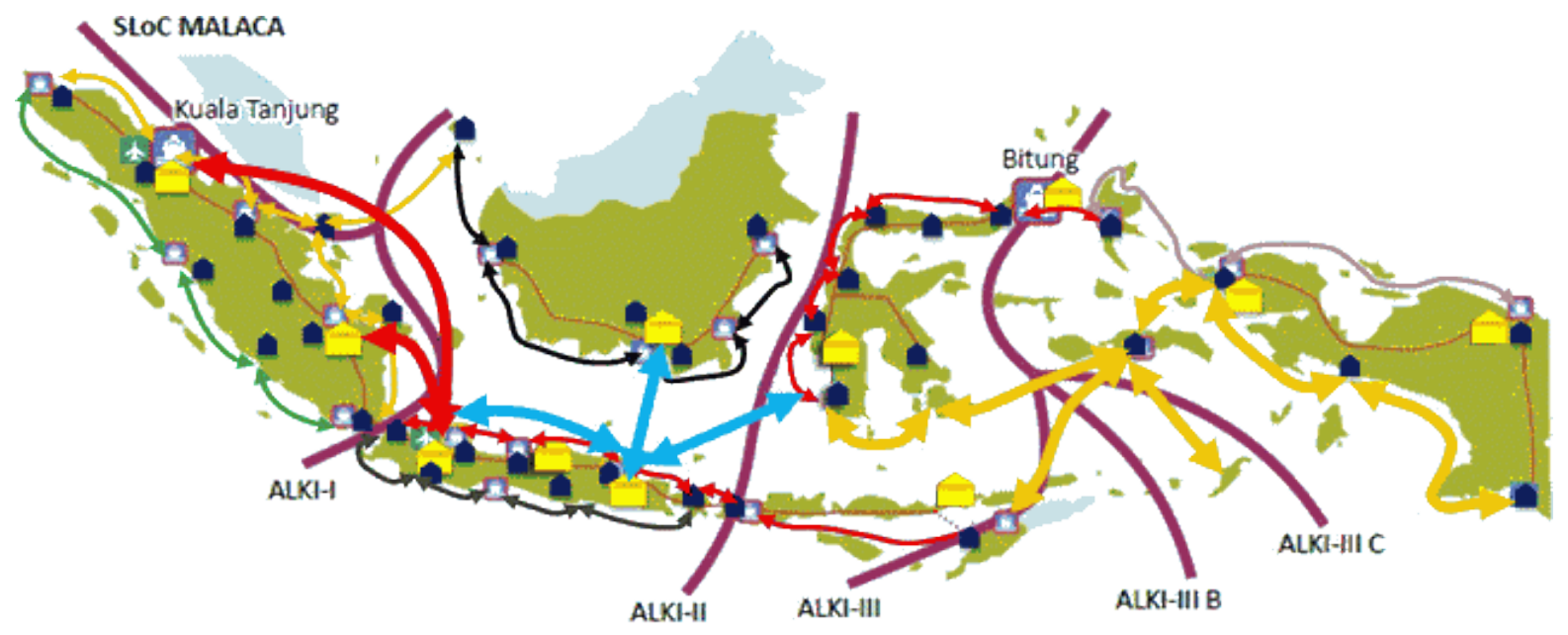

Gambar 2. Alur lalu lintas kepulauan indonesia

Alur Laut Kepualauan Indonesia (ALKI) merupakan konsensus yang ditetapkan pada Peraturan Pemerintah no 37 tahun 2002, dengan membagi wilayah Indonesia untuk dilewati oleh 3 jalur ALKI dengan adanya keputusan IMO pada sidang Marine Safety Comitte ke-69.

ALKI terbentuk setelah United Nations Convention on the Law of the Sea (UNCLOS) tahun 1982 (yang diratifikasi dengan UU No. 17 Tahun 1985) dan dinyatakan sebagai hukum positif internasional sejak 16 November 1994, telah mengakui hak Indonesia sebagai Archipelagic State [2].

Pasca penetapan Status Indonesia sebagai Negara kepulauan, kewajiban pemerintah Indonesia terhadap status tersebut telah diatur 
dalam Pasal 46-53 UNCLOS 1982. Indonesia dapat menentukan alur laut untuk lalu lintas kapal dan pesawat udara bagi negara asing yang akan melewati secara terus menerus dan langsung, serta secepat mungkin melalui atau di atas perairan kepulauannya dan teritorial yang berdampingan dengannya [3].

Sampai saat ini Indonesia telah membuka dan menetapkan jalur ALKI yang terdiri atas ALKI-I Selat Sunda yang di bagian utara bercabang menuju Singapura (A1) dan menuju Laut China Selatan. ALKI II Selat Lombok menuju Laut Sulawesi. Sedangkan ALKI III yang di bagian selatan bercabang tiga menjadi ALKI III A (sekitar perairan Laut Sawu, Kupang), ALKI III B, ALKI III C (sebelah timur Timor Leste), dan ALKI III D (sekitar perairan Aru).

Berdasarkan data tersebut di atas, dimana jumlah anjungan lepas pantai yang sudah tidak beroperasi semakin banyak dan semakin ramainya lalu lintas pelayaran di jalur ALKI terutama ALKI-I, serta mengacu pada Peraturan Pemerintah No. 10 Tahun 2010 tentang kenavigasian dan berdasarkan konsekuensi keanggotaan Indonesia dalam IMO [1], maka Pemerintah Indonesia berkewajiban untuk :

- Anjungan lepas pantai yang sudah tidak beroperasi harus segera dibongkar.

- Anjungan tersebut diatas yang dioperasikan pada kedalaman kurang dari 100 m, harus dibongkar/dipindahkan secara keseluruhan.

- Anjungan yang berada di alur pelayaran internasional harus dibongkar secara keseluruhan.

Ada beberapa pilihan metode untuk menangani permasalahan anjungan lepas pantai yang sudah tidak beroperasi, sebagaimana diperlihatkan pada Gambar 3.

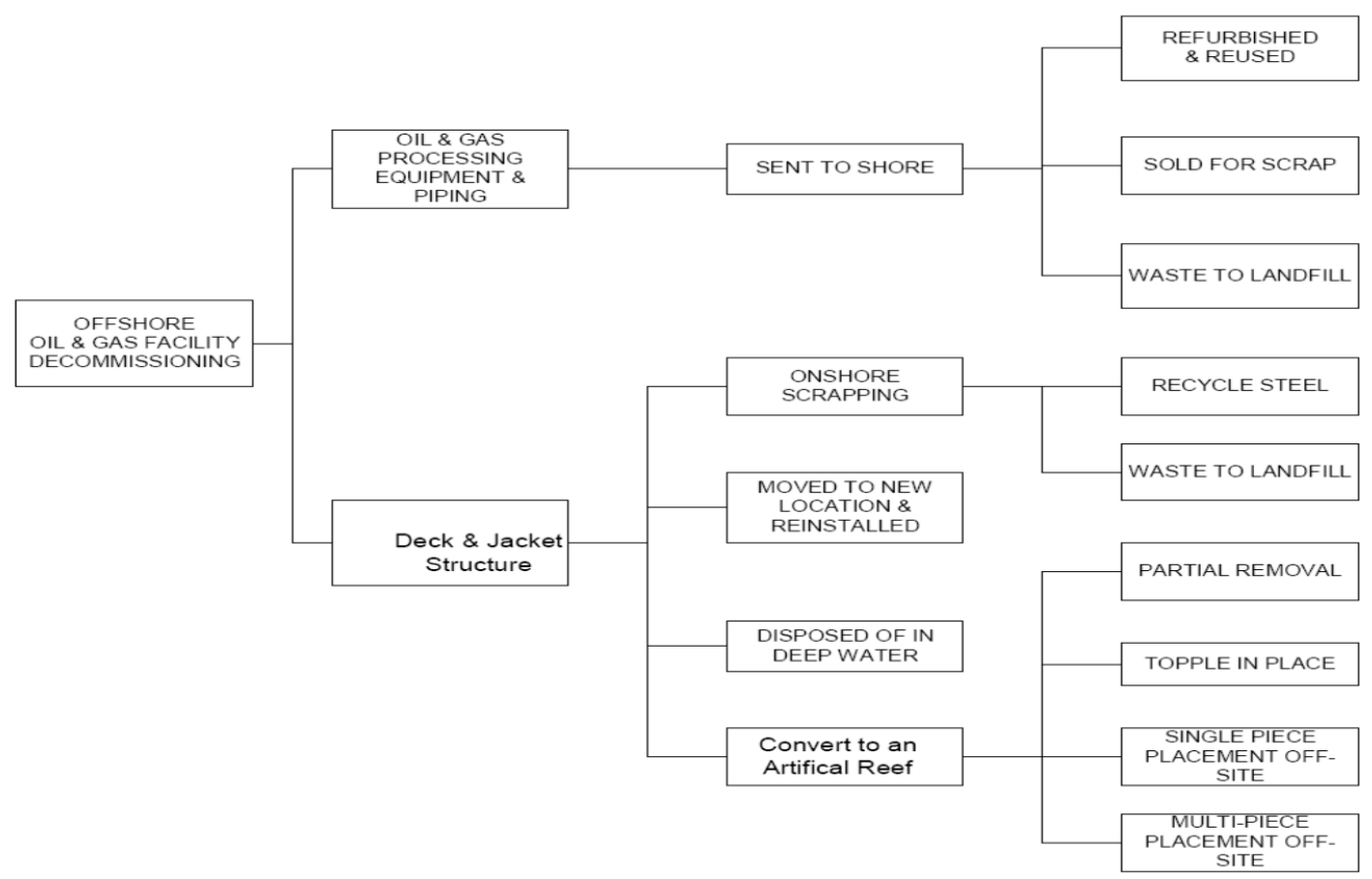

Gambar 3. Pilihan penanganan anjungan lepas pantai yang sudah tidak beroperasi

Dalam rangka untuk mendukung kegiatan pembongkaran anjungan lepas pantai, diperlukan suatu wahana yang dapat dipergunakan untuk melakukan kegiatan pembongkaran dan pengangkutan anjungan menuju lokasi yang dituju. Agar diperoleh satu wahana yang dapat berfungsi secara optimal maka dibutuhkan suatu perencanaan dan analisis yang meliputi perencanaan ukuran utama kapal, bentuk badan kapal, tata letak ruang (General Arrangement), analisis stabilitas kapal pada berbagai kondisi yang direncanakan.

Pada paper ini akan diuraikan kajian stabilitas kapal berbentuk kapal tongkang (barge), pada 
berbagai kondisi seperti kondisi departure, loading dan arrival. Dari analisis ini diharapkan akan diperoleh gambaran stabilitas kapal dibandingkan dengan kriteria stabilitas yang berlaku secara Internasional. Suatu metode pendekatan numerik dengan menggunakan code yang ada, maka diperoleh hasil-hasil perhitungan stabilitas kapal pada kondisi yang direncanakan.

Adapun hasil analisis stabilitas menunjukkan bahwa stabilitas kapal pada kondisi departure, loading dan arrival telah memenuhi kriteria/persyaratan stabilitas yang berlaku, pada kondisi kapasitas tangki tertentu.

\section{Kajian Pustaka}

Suatu struktur terapung dapat dikatakan memiliki stabilitas yang baik jika struktur tersebut mampu mengapung dengan baik, terlebih saat mengalami gaya-gaya dari luar seperti angin dan gelombang, gaya-gaya luar saat bongkar muat, dan lain-lain hingga dapat mengembalikan pada posisi tegak semula [4]. Sebuah kapal dikatakan memiliki stabilitas awal jika mampu kembali ke posisi semula setelah gaya yang menyebabkan kemiringan kapal ditiadakan. Gaya yang bekerja pada kapal dan mengakibatkan kemiringan pada kapal biasa dikenal dengan Momen Heeling [5].

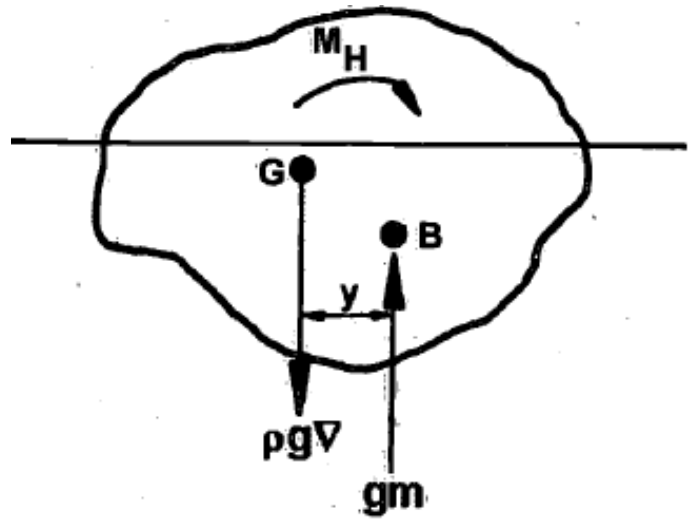

Gambar 4. Momen heeling benda terapung

Jika tidak ada gaya eksternal yang bekerja pada struktur, lengan y akan bernilai 0 , sehingga:

$$
M_{H}=\rho g \nabla \cdot y=g m \cdot y
$$

pada $\mathrm{y}=0$ maka $\mathrm{M}_{\mathrm{H}}=0$

Hal ini berarti bahwa untuk struktur yang berada pada posisi tegak, titik pusat buoancy B dan titik pusat grafitasi akan berada pada satu garis lurus. Jika tidak demikian, maka struktur akan mengalami heeling.

Bilamana ada Momen Heeling (gaya eksternal) yang bekerja pada kapal, maka kapal akan mengalami kemiringan sebesar $\phi$ derajat. Sebagai akibat kemiringan tersebut maka bentuk kapal yang berada di bawah garis air akan mengalami perubahan. Titik pusat buoancy akan bergeser dari B ke B $\phi$ pada garis yang sejajar dengan garis yang melewati titik pusat luasan bidang yang tenggelam dan terangkat (lihat Gambar 5 berikut).

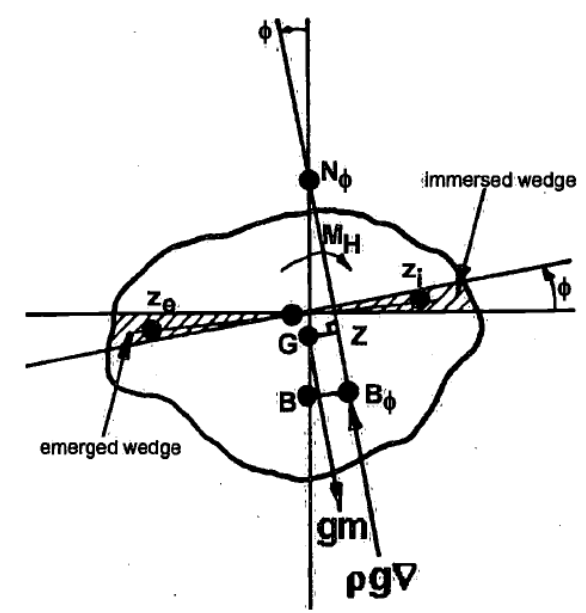

Gambar 5. Keseimbangan benda terapung pada sudut kemiringan $\phi$

Sehingga besarnya Momen Stabilitas pengembali, $\mathrm{M}_{\mathrm{S}}$ dapat dirumuskan:

$$
\begin{gathered}
M_{S}=M_{H} \\
M_{S}=m g \cdot \overline{G Z}
\end{gathered}
$$

Pada kasus terjadinya sudut kemiringan kapal yang besar, maka titik metasenter akan tergantung pada sudut kemiringan kapal dan $\mathrm{N}_{\phi}$.

Dengan demikian, besarnya momen stabilitas statis dapat dituliskan menjadi:

$$
M_{S}=m g \cdot \overline{G N_{\phi}} \sin \phi
$$

Besarnya lengan GZ akan ditentukan oleh sifat-sifat hidrostatis dari bagian struktur yang tenggelam dan titik pusat beratnya. Adapun harga 
$\mathrm{GN}_{\phi}$ dapat ditentukan dengan perumusan sebagai berikut:

$$
\begin{gathered}
\overline{G N_{\phi}}=\overline{K B}+\overline{B N_{\phi}}-\overline{K G} \\
\overline{G N_{\phi}}=\overline{G M}+\frac{1}{2} \overline{B M} \cdot \tan ^{2} \phi
\end{gathered}
$$

Oleh karena lengan stabilitas sangat tergantung pada sudut kemiringan kapal, maka kurva GZ sebagaimana ditunjukkan oleh Gambar berikut, dianggap sangat cocok untuk menilai stabilitas sebuah kapal.

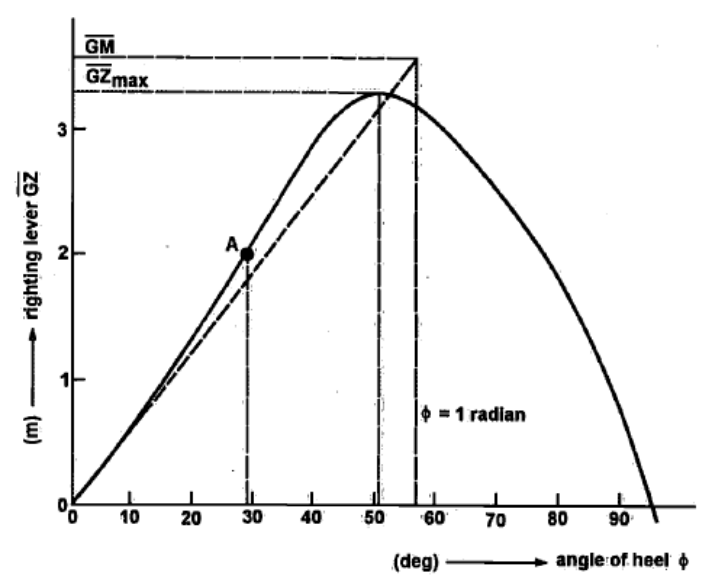

Gambar 6. Kurva stabilitas statis

Beberapa karakteristik yang dianggap penting pada kurva stabilitas statis adalah:

- Slope pada titik origin

Untuk sudut kecil, lengan pengembali sebanding dengan sudut kemiringan. Dengan demikian, tangent kurva GZ menunjukkan tinggi titik metasenter GM.

- GZ maksimum

Harga ini sebanding dengan momen heeling terbesar dimana tidak mengalami capsize (terbalik).

- Rentang Stabilitas

Merupakan rentang sudut kemiringan kapal dimana GZ mempunyai nilai positif.

- Sudut tenggelam geladak kapal

Pada sebagian besar kapal, menunjukkan sudut dimana geladak kapal mulai tenggelam.

- Luasan dibawah kurva stabilitas

\subsection{Stabilitas Saat Loading}

Pada kapal yang menggunakan crane atau alat angkat sejenis, perlu diperhatikan bahwa berat beban yang diangkat bertumpu pada titik suspensi, bukan pada bagian pangkal crane. Dengan demikian maka momen overturning akan cenderung bisa mengakibatkan kapal terbalik. Besarnya momen overturning adalah merupakan hasil kali berat beban dengan jarak horisontal $\left(\mathrm{d}_{1}\right)$ dari titik suspensi (p) terhadap titik buoyancy (B) sebagaimana ditunjukkan oleh Gambar berikut.

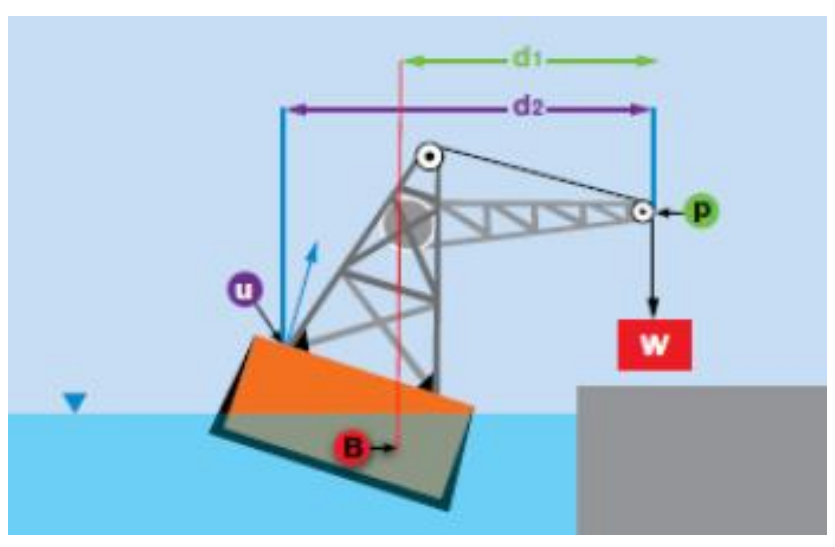

Gambar 7. Momen pada crane saat loading

Gaya angkat terbesar bekerja pada titik sentuh/tangkap terjauh (crane terhadap barge) dari titik suspensi. Momen yang terjadi merupakan hasil kali berat beban yang diangkat dengan jarak horisontal $\left(\mathrm{d}_{2}\right)$ titik suspensi $(\mathrm{p})$ dari titik angkat (u).

Pada analisis stabilitas crane saat mengangkat beban, peningkatan radius akan diikuti dengan penurunan sudut "Boom" dan penurunan besarnya beban. Dengan demikian, penurunan sudut Boom akan meningkatkan stabilitas kapal [6].

Demikian halnya, karena kapal beroperasi pada beberapa sarat yang berbeda terutama saat bongkar muat, maka analisis kapal pada kondisi tersebut tidak dapat dijelaskan dengan pasti. Dengan demikian kurva hidrostatik kapal pada kondisi ini menjadi sangat penting.

2.2. Pengaruh Kapasitas Tangki Ballast Pada Stabilitas Saat Loading

Secara umum, perhitungan kapasitas tangki ballast diperlukan untuk menentukan berat beban yang akan diangkat oleh crane. Semakin besar 
berat beban yang diangkat maka semakin besar volume ballast yang dibutuhkan untuk mendapatkan stabilitas yang baik. Kapasitas air ballast pada kapal didefinisikan sebagai volume tangki/ruangan yang disediakan di kapal untuk proses penyeimbangan yang dinyatakan dalam $\mathrm{m}^{3}$.

Kapasitas volume tangki ballast sangat menentukan tingkat seaworthiness suatu kapal pada kondisi statis dan dinamis. Sebagai contoh, sesuai regulasi yang dikeluarkan oleh Det Norske Veritas [7] untuk kapal tanker berukuran 20.000 ton atau lebih, dipersyaratkan untuk memiliki tangki ballast yang terpisah. Kapasitas tangki ballast tersebut harus sedemikian hingga pada kondisi ballast apapun, sarat dan trim kapal harus memenuhi persyaratan berikut:

- Draft di bagian tengah kapal,

$\mathrm{d}_{\mathrm{m}} \geq 2.0+0.02 \mathrm{~L}$

- Trim stern yang terjadi,

$$
\mathrm{t} \leq 0.015 \mathrm{~L}
$$

Secara umum, kapal kargo dan kapal feri RoRo menggunakan hanya sedikit kapasitas air ballast, yaitu, umumnya sekitar $20 \%$ dari DWT, dengan beberapa perkecualian bahkan lebih dari 40\% DWT. Di sisi lain, untuk kapal angkut cairan dan muatan curah kering (dry-bulk), misalnya, kapal tanker, dry-bulk carrier, membutuhkan jumlah kapasitas air ballast yang lebih besar hingga 30 sampai 50\% dari DWT, yang kurang lebih sekitar $100.000 \mathrm{~m}^{3}$ air ballast per kapal.

\subsection{Kriteria Stabilitas}

Sebagaimana dijelaskan sebelumnya bahwa wahana ini digunakan untuk melakukan pembongkaran dan pengangkutan anjungan lepas pantai yang sudah tidak beroperasi (ALPO), dimana dalam perencanaan stabilitas lebih ditekankan pada kondisi pengangkatan dan pengangkutan ALPO sebagai kondisi yang dianggap kritis. Dalam perencanaan stabilitas intact kapal ini, digunakan beberapa kriteria stabilitas dengan mengacu pada regulasi Badan Klasifikasi seperti DNV serta regulasi yang ditetapkan oleh IMO [8], yang mencakup beberapa kriteria sebagai berikut:
- Harga lengan pengembali GZ pada sudut kemiringan 30 derajat atau lebih, tidak boleh kurang dari 0,02 m.

- Lengan pengembali maksimum harus terjadi pada sudut lebih dari 25 derajat.

Tinggi titik metasenter awal, tidak boleh kurang dari $0.15 \mathrm{~m}$.

\section{Metodologi Penelitian}

Perencanaan dan analisis pengoperasian wahana angkut ALPO dilakukan melalui beberapa tahapan dengan menggunakan pendekatan numerik yang meliputi: penentuan ukuran utama kapal dan bentuk lambung kapal, perhitungan berat kapal dan perhitungan stabilitas kapal dalam berbagai kondisi prosentase kapasitas tangki ballast.

Dalam makalah ini, perhitungan stabilitas kapal lebih ditekankan pada stabilitas statis pada kondisi intact (tidak ada kerusakan/gangguan pada kapal yang berpengaruh terhadap stabilitas kapal). Beberapa skenario yang direncanakan dalam perhitungan stabilitas yang terdiri atas beberapa kondisi operasional sebagai berikut:

- Kondisi saat departure

- Kondisi saat crane menjalankan proses loading

- Kondisi saat arrival

Dalam analisis stabilitas pada kondisi di atas, digunakan beberapa kriteria sebagaimana yang diberikan oleh institusi klasifikasi Det Norske Veritas (DNV) dan International Maritime Organisation (IMO). Berdasarkan kriteria-kriteria yang diberikan, akan dapat ditentukan kualitas stabilitas wahana angkut ALPO.

\section{Hasil-Hasil Penelitian dan Pembahasan}

Berdasarkan perencanaan yang dilakukan, diperoleh ukuran utama dan bentuk lambung kapal sebagaimana ditunjukkan pada Tabel 1 dan Gambar 8.

Hasil-hasil perhitungan stabilitas pada beberapa kondisi yang dianggap penting terkait dengan perencanaan wahana angkut ALPO adalah sebagai berikut: 
- Kondisi Departure (saat kapal akan berangkat berlayar)

Hasil perhitungan ditampilkan dalam bentuk kurva GZ sebagai fungsi sudut kemiringan kapal (heeling) sebagaimana ditunjukkan pada Gambar 9.

- Kondisi Loading (saat crane mengangkat beban)

Oleh karena pada saat crane melakukan loading kapal mengalami kemiringan maka perlu dilakukan proses ballasting dengan mengisi tangki ballast dalam prosentase tertentu (10-100\%) kapasitas tangki hingga memenuhi kriteria stabilitas.
Tabel 1. Ukuran utama wahana angkut ALPO

\begin{tabular}{cccc}
\hline Besaran & Simbol & Nilai & Satuan \\
\hline Panjang antar garis & LPP & 103 & $\mathrm{~m}$ \\
tegak & $\mathrm{Bm}$ & 22 & $\mathrm{~m}$ \\
Lebar tengah kapal & $\mathrm{T}$ & 3 & $\mathrm{~m}$ \\
Sarat & $\mathrm{H}$ & 6 & $\mathrm{~m}$ \\
Tinggi & $\Delta$ & 5760 & Ton \\
Displacement & & &
\end{tabular}

Hasil-hasil perhitungan numerik yang diperoleh dapat dilihat pada Tabel 3-5.
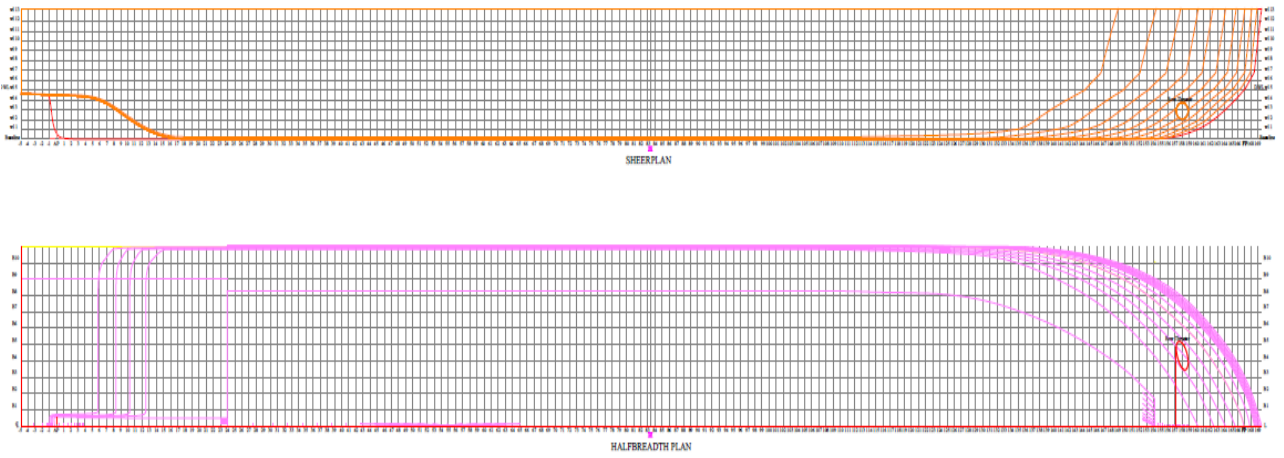

Gambar 8. Lines plan wahana angkut ALPO

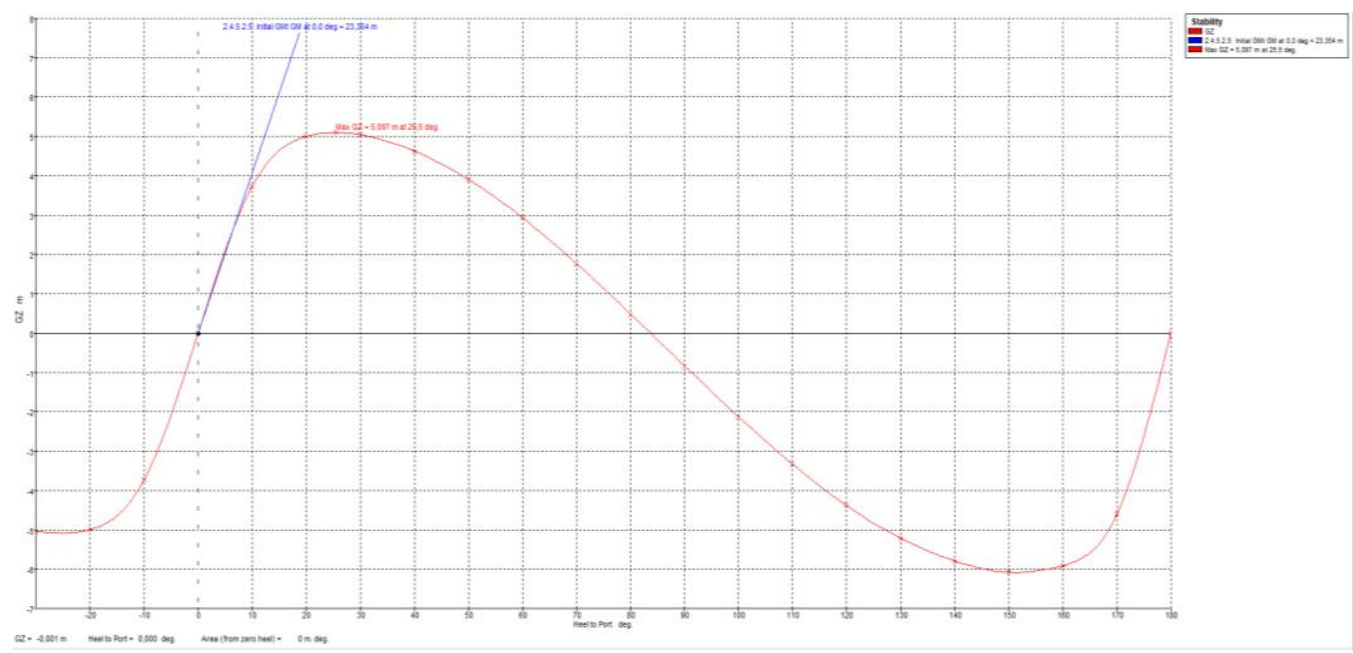

Gambar 9. Kurva GZ sebagai fungsi sudut kemiringan pada saat departure 
Tabel 2. Analisis stabilitas kapal saat departure berdasarkan kriteria

\begin{tabular}{|c|c|c|c|c|c|c|}
\hline Code & Criteria & Value & Units & Actual & Status & $\underset{\%}{\operatorname{Margin}}$ \\
\hline \multirow[t]{6}{*}{ GZ curve criteria } & $\begin{array}{l}\text { Value of GZ at spec, angle or max. GZ } \\
\text { below }\end{array}$ & & & & Pass & \\
\hline & Heel angle at which required GZ is constant & 30,0 & $\operatorname{deg}$ & & & \\
\hline & Required value of GZ at this angle is & 0,200 & $\mathrm{~m}$ & & & \\
\hline & Limited by first downflooding angle & $\mathrm{n} / \mathrm{a}$ & deg & & & \\
\hline & GZ at 25,5 deg shall be greater than (>) & $\mathbf{0 , 2 3 6}$ & $\mathbf{m}$ & 5,097 & Pass & $+2062,3$ \\
\hline & Angle at which max. GZ occurs & & & & & \\
\hline \multirow{3}{*}{ GZ curve criteria } & Angle of max. GZ & & & & Pass & \\
\hline & Limited by first downflooding angle & $\mathrm{n} / \mathrm{a}$ & $\operatorname{deg}$ & & & \\
\hline & Shall be greater than $(>)$ & 25,0 & $\operatorname{deg}$ & 25,5 & Pass & $+1,82$ \\
\hline \multirow{3}{*}{$\begin{array}{l}2.4 \text { Offshore } \\
\text { supply vessel }\end{array}$} & 2.4.5.2.5: Initial GMt & & & & Pass & \\
\hline & spec. heel angle & 0,0 & $\operatorname{deg}$ & & & \\
\hline & Shall be greater than $(>)$ & 0,150 & $\mathbf{m}$ & 23,354 & Pass & +15469 \\
\hline
\end{tabular}

Tabel 3. Analisis stabilitas kapal pada kondisi ballast $10 \%$ kapasitas tangki

\begin{tabular}{|c|c|c|c|c|c|c|}
\hline Code & Criteria & Value & Units & Actual & Status & $\underset{\%}{\operatorname{Margin}}$ \\
\hline \multirow[t]{6}{*}{ GZ curve criteria } & $\begin{array}{l}\text { Value of GZ at spec, angle or max. GZ } \\
\text { below }\end{array}$ & & & & Pass & \\
\hline & Heel angle at which required GZ is constant & 30,0 & $\operatorname{deg}$ & & & \\
\hline & Required value of $\mathrm{GZ}$ at this angle is & 0,200 & $\mathrm{~m}$ & & & \\
\hline & Limited by first downflooding angle & $\mathrm{n} / \mathrm{a}$ & $\operatorname{deg}$ & & & \\
\hline & $\begin{array}{l}\mathbf{G Z} \text { at } 21,8 \text { deg shall be greater than }(>) \\
\text { Intermediate values }\end{array}$ & 0,275 & $\mathbf{m}$ & 6,175 & Pass & $+2145,4$ \\
\hline & Angle at which max. GZ occurs & & $\operatorname{deg}$ & 21,8 & & \\
\hline \multirow[t]{3}{*}{ GZ curve criteria } & Angle of max. GZ & & & & Fail & \\
\hline & Limited by first downflooding angle & $\mathrm{n} / \mathrm{a}$ & deg & & & \\
\hline & Shall be greater than $(>)$ & 25,0 & deg & 21,8 & Fail & $+12,73$ \\
\hline \multirow{2}{*}{$\begin{array}{l}2.4 \text { Offshore } \\
\text { supply vessel }\end{array}$} & 2.4.5.2.5: Initial GMt & & & & Pass & \\
\hline & $\begin{array}{l}\text { spec. heel angle } \\
\text { Shall be greater than (>) }\end{array}$ & $\begin{array}{r}0,0 \\
\mathbf{0 , 1 5 0}\end{array}$ & $\begin{array}{l}\operatorname{deg} \\
\mathbf{m}\end{array}$ & 18,643 & Pass & +12328 \\
\hline
\end{tabular}

Tabel 4. Analisis stabilitas kapal pada kondisi ballast $30 \%$ kapasitas tangki

\begin{tabular}{|c|c|c|c|c|c|c|}
\hline Code & Criteria & Value & Units & Actual & Status & $\underset{\%}{\text { Margin }}$ \\
\hline \multirow[t]{6}{*}{ GZ curve criteria } & $\begin{array}{l}\text { Value of GZ at spec, angle or max. GZ } \\
\text { below }\end{array}$ & & & & Pass & \\
\hline & Heel angle at which required GZ is constant & 30,0 & deg & & & \\
\hline & Required value of $\mathrm{GZ}$ at this angle is & 0,200 & $\mathrm{~m}$ & & & \\
\hline & Limited by first downflooding angle & $\mathrm{n} / \mathrm{a}$ & $\operatorname{deg}$ & & & \\
\hline & $\begin{array}{l}\text { GZ at } 24,5 \text { deg shall be greater than }(>) \\
\text { Intermediate values }\end{array}$ & 0,244 & $\mathbf{m}$ & 5,550 & Pass & $+2170,4$ \\
\hline & Angle at which max. GZ occurs & & $\operatorname{deg}$ & 24,5 & & \\
\hline \multirow[t]{3}{*}{ GZ curve criteria } & Angle of max. GZ & & & & Fail & \\
\hline & Limited by first downflooding angle & $\mathrm{n} / \mathrm{a}$ & deg & & & \\
\hline & Shall be greater than $(>)$ & 25,0 & $\operatorname{deg}$ & 24,5 & Fail & $+1,82$ \\
\hline \multirow{2}{*}{$\begin{array}{l}2.4 \text { Offshore } \\
\text { supply vessel }\end{array}$} & 2.4.5.2.5: Initial GMt & & & & Pass & \\
\hline & $\begin{array}{l}\text { spec. heel angle } \\
\text { Shall be greater than }(>)\end{array}$ & $\begin{array}{r}0,0 \\
\mathbf{0 , 1 5 0}\end{array}$ & $\begin{array}{l}\operatorname{deg} \\
\mathbf{m}\end{array}$ & 17,273 & Pass & +11415 \\
\hline
\end{tabular}


Tabel 5. Analisis stabilitas kapal pada kondisi ballast $40 \%$ kapasitas tangki

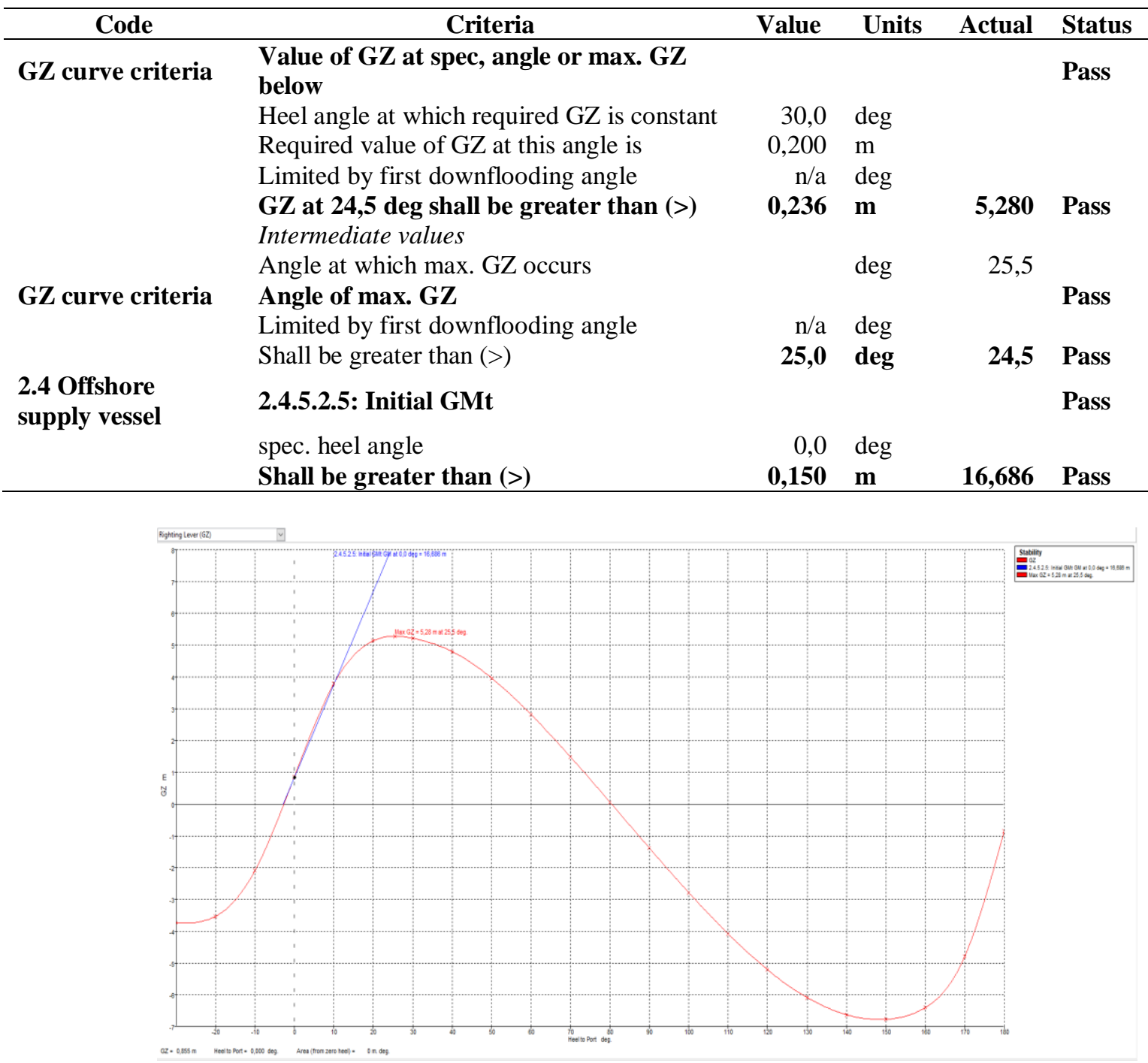

Gambar 10. Kurva GZ sebagai fungsi sudut kemiringan pada $40 \%$ kapasitas tangki ballast

Tabel 6. Analisis stabilitas kapal saat kondisi arrival

\begin{tabular}{|c|c|c|c|c|c|c|}
\hline Code & Criteria & Value & Units & Actual & Status & $\begin{array}{c}\text { Margin } \\
\%\end{array}$ \\
\hline \multirow[t]{6}{*}{ GZ curve criteria } & $\begin{array}{l}\text { Value of GZ at spec, angle or max. GZ } \\
\text { below }\end{array}$ & & & & Pass & \\
\hline & Heel angle at which required GZ is constant & 30,0 & $\operatorname{deg}$ & & & \\
\hline & Required value of GZ at this angle is & 0,200 & $\mathrm{~m}$ & & & \\
\hline & Limited by first downflooding angle & $\mathrm{n} / \mathrm{a}$ & $\operatorname{deg}$ & & & \\
\hline & $\begin{array}{l}\text { GZ at } 24,5 \text { deg shall be greater than (>) } \\
\text { Intermediate values }\end{array}$ & 0,236 & $\mathbf{m}$ & 3,913 & Pass & $+1560,06$ \\
\hline & Angle at which max. GZ occurs & & $\operatorname{deg}$ & 25,5 & & \\
\hline \multirow[t]{3}{*}{ GZ curve criteria } & Angle of max. GZ & & & & Pass & \\
\hline & Limited by first downflooding angle & $\mathrm{n} / \mathrm{a}$ & $\operatorname{deg}$ & & & \\
\hline & Shall be greater than $(>)$ & 25,0 & deg & 25,5 & Pass & $+1,82$ \\
\hline \multirow{3}{*}{$\begin{array}{l}2.4 \text { Offshore } \\
\text { supply vessel }\end{array}$} & 2.4.5.2.5: Initial GMt & & & & Pass & \\
\hline & spec. heel angle & 0,0 & $\operatorname{deg}$ & & & \\
\hline & Shall be greater than $(>)$ & $\mathbf{0 , 1 5 0}$ & m & 16,686 & Pass & $+9684,67$ \\
\hline
\end{tabular}




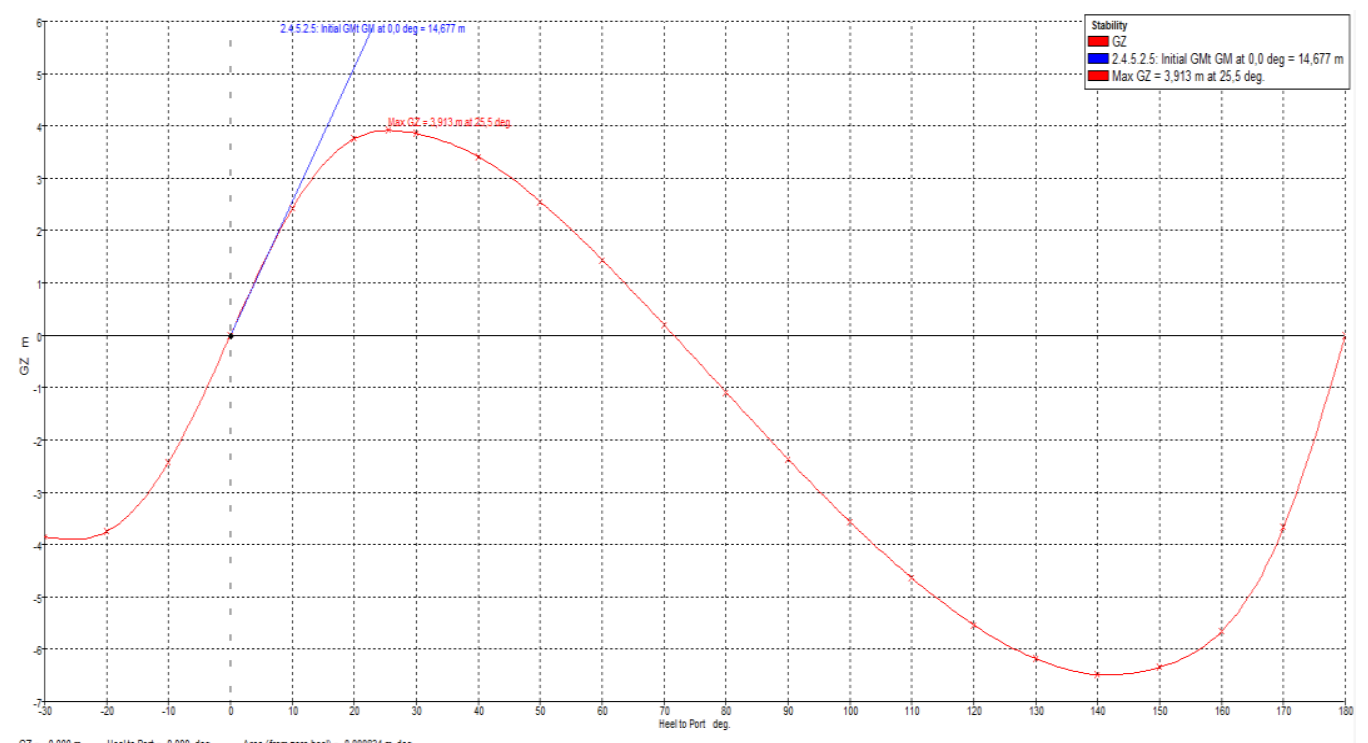

Gambar 11. Kurva GZ sebagai fungsi sudut kemiringan pada saat arrival

- Kondisi Arrival (saat berlayar dengan membawa beban di geladak)

Pada kondisi ini di geladak kapal sudah ada muatan berupa potongan ALPO. Adapun hasilhasil perhitungan yang diperoleh dapat dilihat pada Tabel 6 dan Gambar 11.

Berdasarkan pada hasil-hasil pemodelan numerik sebagaimana ditampilkan di atas, terlihat bahwa kapal saat departure mempunyai stabilitas yang cukup baik karena ketiga kriteria yang digunakan dapat dipenuhi.

Hasil-hasil pemodelan numerik wahana angkut ALPO saat crane melakukan aktifitas pengangkatan beban menunjukkan bahwa pada proses pengisian tangki ballast untuk mengembalikan momen yang terjadi akibat berat beban, pada pengisian tangki ballast hingga 30\% kapasitas semua tangki ballast kapal, salah satu kriteria stabilitas kapal yaitu kriteria kurva GZ terkait dengan persyaratan deck immersion yang terjadi masih belum dapat dipenuhi. Kriteria ini baru dapat dipenuhi pada kondisi pengisian tangki ballast pada kondisi $40 \%$ kapasitas tangki ballast.

Adapun hasil pemodelan numerik wahana angkut ALPO pada saat arrival, yaitu kondisi dimana ada sejumlah muatan (ALPO) di atas geladak kapal, menunjukkan bahwa ketiga kriteria stabilitas bisa dipenuhi dengan baik.

\section{Kesimpulan}

Berdasarkan data yang ada dan kajian dengan menggunakan metode pendekatan numerik, dapat diambil beberapa kesimpulan sebagai berikut:

- Terdapat kurang lebih 449 Anjungan Lepas pantai Pasca Operasi (ALPO) dan memiliki potensi gangguan terhadap keselamatan pelayaran, sehingga dianggap perlu untuk segera dibongkar atau dipindahkan.

- Dibutuhkan satu perencanaan wahana angkut ALPO yang mampu menjalankan fungsinya serta memenuhi standar perencanaan diantaranya memiliki kualitas stabilitas intact yang baik dengan mengacu pada kriteria yang diberikan oleh DNV dan IMO.

- Dengan satu metode pendekatan numerik, dapat diketahui kualitas stabilitas wahana angkut ALPO pada saat departure, arrival dan khususnya saat loading sebagai fungsi prosentase kapasitas tangki ballast kapal.

\section{Referensi}

[1] IMO (1989), "Guidelines and Standard for the Removal of Offshore Installations and Structures on the Continental Shelf and in the Exclusive Economic Zone", (IMO Resolution A.672 (16)).

[2] Wahyono,S.K. (2007), "Indonesia Negara Maritim Jakarta”, Teraju (Anggota IKAPI). 
[3] Budiman, A. (2010)," Pembinaan Wilayah Negara Untuk Kepentingan Pertahanan, Departemen Pertahanan".

[4] Thomas, C. Gillmer and Bruce Johnson (1982), "Introduction to Naval Architecture", E. \& F. N. Spon Ltd.

[5] Gudmestad, O.T. 92007), "Stabilitet, Lecture Notes in Marine Technology", University of Stavenger.
[6] Ephraim M.E. and Douglas, I. E. (1991), "Technical Report on Analysis and Design of Support System for Weatherford Gulf Master G 1 5F Crane on the Anini-1 Rig.

[7] DNV (2000)," Rules of Classification of Ships. Managing Risk - Electronic Rulebook". Det Norske Veritas, Hovik, Norway.

[8] IMO (2002), “ Code on Intact Stability for all Types of Ships”, Resolutions A.749 (18), Norway. 